\title{
BIOSORPTION OF RADIOACTIVE ELEMENTS FROM PHOSPHOGYPSUM BY SACCHAROMYCES CEREVISIAE
}

\author{
Saadia M. Easa', Mohsen M. Ali², Nora S. Gad², Mahmoud. M. El-Maadawy², and \\ Dina M. Elgohary ${ }^{1^{*}}$
}

${ }^{1}$ Microbiology Department, Faculty of Science, Ain Shams University

${ }^{2}$ Nuclear Materials Authority. P.O. Box 530, El Maadi, Cairo, Egypt

Corresponding author: dinamagdy531@yahoo.com

\begin{abstract}
Phosphogypsum (PG) is an important industrial by-product derived from phosphoric acid and phosphate fertilizer manufactures by dehydrates process. Using Saccharomyces cerevisiae as a biosorbant for uranium (U), thorium(Th) and radium (Ra) from (PG) by Appling different carbon sources such as maltose, sucrose, starch, lactose, fructose and glucose. Starch, maltose and fructose media give most uranium biosorption capacity $(13,13$ and 14 ppm) while in sucrose and glucose media give (20 and $22 \mathrm{ppm})$. Maltose and starch media give the highest thorium biosorption capacity. At the same time sucrose and glucose give moderate biosorption.
\end{abstract}

\section{Keywords:}

Biosorption, Phosphogypsum, Radioactive, Saccharomyces cerevisiae.

\section{Introduction}

Phosphogypsum (PG) is a waste by-product from the processing of phosphate rock by the "wet acid method" of fertilizer production, which currently accounts for over $90 \%$ of phosphoric acid production. World PG production is variously estimated to be around 100-280 million tons per year (Yang et al., 2009; Parreira et al., 2003) and the main producers of phosphate rock and phosphate fertilizers are located in the USA, the former USSR, China, Africa and the Middle East. The phosphate industry is also an important contributer to national economies in many developing countries. 
The mineralogical composition of phosphate ore, as described by various researchers (Carbonell-Barrachina et al., 2002; Oliveira and Imbernon, 1998), is dominated by carbonate fluorapatite $\left[\mathrm{Ca}_{10} \mathrm{~F}_{2}\left(\mathrm{PO}_{4}\right)_{6} \mathrm{CaCO}_{3}\right]$, goethite and quartz, with minor amounts of Al-phosphates, anatase, magnetite, monazite and barite. Heavy metals and trace elements such as cadmium $(\mathrm{Cd})$ and nickel (Ni) are also detected. Phosphate ores are naturally highly radioactive, and their radioactivity originates mainly from ${ }^{238} \mathrm{U}$ and ${ }^{232} \mathrm{Th}$.

Phosphogypsum (PG) is an important industrial by-product derived from phosphoric acid and phosphate fertilizer manufactures by dehydrates process. The amount of this waste exceeds considerably than the mass of the product, because the amount of the waste PG being produced in the acid ranges from 4.5 to 5.5 ton per ton of $\mathrm{P}_{2} \mathrm{O}_{5}$ in terms of dry matter. The Phosphogypsum (PG) is separated from the medium of dissolved phosphate ore in sulphuric acid by filtration. Whereas the major part of the pure $\mathrm{P}_{2} \mathrm{O}_{5}$ is obtained from the sediment by means of a counter current washing with water (Guidelines for Management, 2014).

Uranium is one of the most abundant radionuclides found in soils, sediments, and groundwater. Although biological activity cannot destroy or remove uranium, soluble and mobile $\mathrm{U}(\mathrm{VI})$ can be microbiologically precipitated and immobilized by its reduction to insoluble U(IV) oxide (Anderson and Lovley,2002; Lloyd,2003) Therefore, in situ microbial reduction of U (VI) to $\mathrm{U}$ (IV) is a promising bioremediation strategy for containing uranium plumes. Microbial U (VI) reduction has been observed in two major bacterial groups: the metal-reducing bacteria (e.g., Geobacter spp. and Shewanella spp) (Lloyd et al, 2003; Lovley, 2002; Nealson et al.,2002) and the sulfatereducing bacteria (e.g., Desulfovibrio spp.) Some of these microorganisms have been reported to conserve energy for growth from U(VI) reduction. While others reduce uranium without apparent energy gain (Sani et al., 2002; Shelobolina et al.,2004). (Xinjin Liang et al., 2016) demonstrate that phosphatase-mediated uranium bio-mineralization can occur in yeasts supplied with an organic phosphate substrate as sole source of phosphorus.

Saccharomyces cerevisiae immobilized on silica gel showed good biosorption properties in removing uranium from dilute aqueous solution (Aytas et al. 2011). S. cerevisiae also shows some properties of uranium biomineralization through formation of a U(IV)-bearing precipitate during growth in a high-phosphate medium (Ohnuki et al. 2005). Uranium removal by yeasts has mainly focused on $S$. cerevisiae, while other yeast species have 
received little attention (Ohnuki et al. 2005; Sakamoto et al; 2007; Sarri et al. 2009).

Liu Mingxue et al., (2010) demonstrated that uranium interacted with yeast cell surfaces, as well as culture medium, and produced uranium precipitate on cell surfaces.

It was proved that yeast extract was the best source for sulphate -reducing bacteria with phosphogypsum, followed by ammonium chloride. The presence of nitrate had an inhibitory effect on the process of sulfate reduction bacteria (Samia et, al 2005). While It was demonstrated that anaerobic sulphidogenic microorganisms were isolated from soil polluted by oil-derived products and grown using the microcosms method. The cultures were grown in minimal and post gate media with phosphogypsum (PG) as the sole electron acceptor and with lactate, casein or lactose as the sole carbon source. The most effective was the assemblage in post gate medium with lactose as the sole carbon source. After growth, the residues were weighed and, in all cases, a distinct mass reduction of phosphogypsum was observed in comparison to the $6 \mathrm{~g} \mathrm{l}^{-1}$ introduced to the medium. Diffractometric studies of the residues confirmed the presence of calcite and apatite. The presence of these mineral phases in the residues allows their application as agricultural fertilizers (Dorota et al., 2009). It was demonstrated that the biotransformation of phosphogypsum in culture reducing bacteria from crude petroleum-refining waste waters results $66 \%$ utilization of PG introduce into the culture $(5 \mathrm{~g} / \mathrm{L})$ which reflect the active biotransformation of PG by the community selected from the waste water (Wolicka et al., 2005).

The present work aimed to partially eliminate the radioactive elements by using Saccharomyces cerevisiae grown in different carbon sources such as maltose, sucrose, starch, lactose, fructose, and glucose.

\section{Materials and Methods}

-Materials: Phosphogypsum (PG) used in this work was obtained kindly from Abu-Zaabal Fertilizer Co., Cairo, Egypt as filter cake and directly dried in the sun.

-Methods of analysis: The collected samples were identified through collaborative techniques of chemical analysis, such as spectrophotometeric techniques and other applied techniques include: scanning electron microscope (ESEM) infra-red spectroscopy, XRF (X-ray fluorescence), and radiometric analysis. 


\section{A-Environmental Scanning Electron Microscope:}

Environmental scanning electron microscope (ESEM), Philips XL 30 was applied for brief qualitative investigation of minerals in each sample for quick semi quantitative of the obtained products under the usual conditions are low vacuum (Erdmanna et al; 2000). An applied voltage from $5-30 \mathrm{kV}$, the back scatter electron detector (BSE), and occasionally gas scatter electron detector (GSE) are used for photomicrographs. The attached unite of energy dispersive $\mathrm{X}$-ray (EDX) is used to obtain the semi quantitative chemical analysis.

\section{B-Infrared Spectroscopy:}

Samples were subjected to infrared spectroscopy in order to determine the function groups of the samples. The model of IR spectroscopy is Naxux 670 FTIR, Company name (Nicollet) USA. The Range of spectrum was usually performed from 4000 to $400 \mathrm{Cm}^{-1}$, with Resolution $4 \mathrm{Cm}^{-1}$ (Peter, 2011).

\section{C-X -ray Fluorescence:}

The X-ray fluorescence technique, (XRF), was used to determine the trace element contents (Gravani et al, 2006) using PHILIPS X' Unique-II spectrometer with automatic sample changer PW 1510, (30 positions). This instrument is connected to a computer system using X-40 program for spectrometry. The trace elements concentrations are calculated from the program's calibration curves which were set up according to international reference materials, (standards). The trace elements were measured by calibrating the system under the conditions of Rh-target tube, LiF-420 crystal, gas flow proportional counter, (GFPC), coarse collimators, vacuum, $30 \mathrm{kV}$ and $40 \mathrm{~mA}$ for the determination of Vanadium (V), Chromium (Cr), Cobalt $(\mathrm{Co})$, Nickel $(\mathrm{Ni})$, copper $(\mathrm{Cu})$,Zinc $(\mathrm{Zn})$ and Gallium $(\mathrm{Ga}), 70 \mathrm{kV}$ and 15 $\mathrm{mA}$, for Rubdium (Rb), Strontium (Sr), Yttrium (Y), Zirconium ( $\mathrm{Zr}$ ) and Niobium $(\mathrm{Nb})$ and $100 \mathrm{kV}$ and $10 \mathrm{~mA}$ for the determination of Barium (Ba) and Palladium $(\mathrm{Pb})$, (Viswanathan, 1989). The detection limit is the lowest concentration, and it is function of the level of background noise relative to an element signal, (Norrish and Chappell, 1967). The detection limit for the elements measured by XRF technique is estimated at $2 \mathrm{ppm}$ for Rubidum $(\mathrm{Rb})$, Niobium ( $\mathrm{Nb}$ ), Gallium (Ga), Cobalt (Co), Yttrium (Y) and Strontium $(\mathrm{Sr})$ and at $8 \mathrm{ppm}$ for Palladium $(\mathrm{Pb})$ and Copper $(\mathrm{Cu})$ and $5 \mathrm{ppm}$ for other measured trace elements.

\section{D-Chemical analysis:}

The chemical analyses of radiometric elements were carried out using measurements by portable gamma-ray spectrometer (model GS 256 and model GS-512 made in Czechoslovakia), with NaI (T1) detector of $75 \times$ 
$75 \mathrm{~mm}^{2}$. This instrument also measures eU and eTh in their daughters in parts per millions (ppm). Uranium concentration was determined spectrophotometrically by Arsenazo Ш method after extraction using tributyl phosphate in toluene against regent blank at wave length $650 \mathrm{~nm}$ (Marczenko,1986).

\section{E-Radiometric analysis:}

These samples were prepared for gamma-ray spectrometric analysis in order to determine their uranium, thorium, radium and potassium contents by using multi channel analyzer of $\gamma$-ray detector (Gamma-Spectrometer technique). The instrument used in determination of the four radioactive elements consists of a Bicron scintillation detector $\mathrm{NaI}$ (Tl) 76x76 mm, hermetically sealed with the photomultiplier tube in aluminum housing. The tube was protected by a copper cylinder protection of thickness $0.6 \mathrm{~cm}$ against induced $\mathrm{X}$ ray and a chamber of lead bricks against environmental radiation. Uranium, thorium, radium and potassium were measured by using four energy regions representing Th-234, $\mathrm{Pb}-212, \mathrm{~Pb}-214$ and $\mathrm{K}-40$ at $93 \mathrm{kV}, 239 \mathrm{kV}, 352$ $\mathrm{kV}$, and $1460 \mathrm{kV}$. The measurements were carried out in sample plastic containers, cylindrical in shape, $212.6 \mathrm{~cm}^{3}$ volumes with $9.5 \mathrm{~cm}$ average diameter and $3 \mathrm{~cm}$ height. The rock sample was crushed to about $1 \mathrm{~mm}$ grain size, and then the container was filled with about 300-400 gm of the crushed sample sealed well and left for at least 21 days to accumulate free radon to attain radioactive equilibrium. The relation between the percentage of Rn-222 accumulation and time increase till reaching the steady stage after about 38 days (Matolin, 1991).

\section{Biological system adaptation}

\section{A-Source of Saccharomyces cerevisiae:}

Saccharomyces cerevisiae used in this work was provided by EL-Hwamdiyah Company of yeast and sugar Giza, Egypt.

\section{B-Media used:}

Glucose-peptone-yeast extract agar medium consist of $(\mathrm{g} / \mathrm{L})$

Yeast extracts 3, Peptone 5, Glucose 10, Agar 15, and Dist. water $1000 \mathrm{ml}$. The $\mathrm{pH}$ of the media was adjusted to 7.5 by using $\mathrm{pH}$-Meter model (schott. Germany). The instrument was calibrated before measurement using two successive standard buffer solutions (4 - 7 or $7-10)$, the obtained glucose peptone -yeast-extracts agar media was melted and poured into Petri dishes and then left to solidify, by using a sterile inoculation needle a loop full of one of colonies was taken and streaked on the surface of the solidified agar plates, 
followed by incubation for 72 hours at $30^{\circ} \mathrm{C}$.sub culture was prepared by addition of pure Saccharomyces cerevisiae colonies on slants of glucose peptone yeast agar .

\section{C-Preparation of liquid media:}

In the present study, fifty $\mathrm{ml}$ of Glucose-peptone yeast extracted previously from prepared medium were added to $50 \mathrm{gm}$ of phosphogypsum in conical flask and incubated for 21 days at $30^{\circ} \mathrm{C}$, afterwards all flasks were sealed with removable cotton. After separation the media, the result of phosphogypsum was dried and weighted then subjected to XRF, chemical analysis for radiometric elements infrared analysis, and scanning electron microscope as mentioned before.

\section{D-Cultivation Condition for Saccharomyces cerevisiae:}

In the experimental work, a known weight of phosphogypsum sample (about $50 \mathrm{gm}$ ) was taken to the culture liquid media of usually $1000 \mathrm{ml}$. Several factors were tested during laboratory work such as different carbon sources like glucose, lactose, sucrose, starch and fructose. The usual amount of carbon source added was $20 \mathrm{~g} / \mathrm{L}$ was either from glucose, sucrose, lactose, fructose and starch. These carbon sources were used separately in the preparation of media in each experiment.

\section{Results and Discussion}

a) A series of experiments were carried out and the results were measured for the prospected elements (as oxides) via Scan Electron Microscope. The results of the analysis are summarized in Table(1) and presented in Figures (1) comparing the elemental level in the control bulk sample and their levels after treatment with different carbon sources, it is obvious that, there is no pronounced effect (retention or decrease) in most elements through all the utilized carbon source except for $\mathrm{P}_{2} \mathrm{O}_{5}, \mathrm{SO}_{3}$ groups which may be attributed to the nutrient nature of these anions (may be exhausted and concentrated as a natural bio feed for the organism), some cations such as $\mathrm{Ca}^{2+}$ showed small decrease in the level with same carbon source which may be attributed to the same reason as the former groups. With respect to most of other cations one can judge that there are a marked increase for their elemental levels due to their concentration in the media after extracting others to compensate the weight formula of the substrate. In other words, $\mathrm{Na}, \mathrm{Al}, \mathrm{Si}, \mathrm{K}$ and $\mathrm{Fe}$ in the sample give the same or higher concentration than the original sample in the most six carbon sources. Some elements can be detected after treatment due 
to the aforementioned reasons e.g. Mg, while the other could not be detected e.g Ti. Looking for U, Th, it was so clear that, a good trend for their extraction (retention or adsorption) under all utilized extraction conditions.

b) The phosphogypsum samples resulted after applying different carbon sources were subjected to infrared (IR) analysis. The profiles of the different samples for different sources were collected and demonstrated in Fig (2). All profiles give nearly the alcoholic hydroxyl group production, $\mathrm{CO}^{-}$imides group at $1636-1641 \mathrm{~cm}^{-1}, \mathrm{C} \equiv \mathrm{C}, \mathrm{C} \equiv \mathrm{N}, \mathrm{N} \equiv \mathrm{N}$ and $\mathrm{C}-\mathrm{O}-\mathrm{C}$ on the other hand $\mathrm{CH}$ aliphatic noticed with all carbon source except for glucose which support the opportunity of glucose to be utilized during the course of the factor of different carbon source due to the presence of hydroxyl group alone without formation any interfering capturing groups which may increase the selectivity of the source.

C) X-Ray fluorescence analysis for phosphogypsum samples after applying different carbon source is gathered and manifested in Table (2). From the table it is clear that sulphar represented the major cationic constituent of the experiments course with different carbon sources. While calcium came as minor constituent in all experiments further trace elements nearly the same during all experiments like ( $\mathrm{Mn}, \mathrm{Cr}, \mathrm{Cu}, \mathrm{Zn}, \mathrm{Sr}, \mathrm{Y}, \mathrm{Zr}, \mathrm{Si}, \mathrm{Fe}, \mathrm{K}$ and $\mathrm{Ti}$ ) compared with the bulk sample. Applying lactose sugar as carbon source gave the same major (S) and minor (Ca) elements as the major sample while rubidium appeared and $\mathrm{Ag}$, $\mathrm{Pd}$ disappeared in trace element group using $\mathrm{X}$ ray fluorescence analysis. The entire utilized carbon sources give the same results for major and minor analysis as the major samples, namely sulphar and calcium respectively.

Analysis of phosphogypsum sample after treatment while using glucose sugar as carbon source prevails the presence of $\mathrm{Ni}$ and absence of Pd and $\mathrm{Ag}$ when compared with the original untreated control sample as shown in Table (2). Sucrose results appear $\mathrm{Rb}$ and $\mathrm{Cl}$ and disappear of $\mathrm{Pd}$ and $\mathrm{Ag}$. While in starch utilization as carbon source after treatment assure the absence of Pd and $\mathrm{Ag}$ without the appearance or concentration of other cations and anions. Niobium and rubidium were detected when using other carbon source (Fructose sugar) in the same time $\mathrm{Nb}$ and $\mathrm{Rb}$ in addition to $\mathrm{Ni}$ were detected with maltose. While $\mathrm{Pd}$ and $\mathrm{Ag}$ were undetected during the application of the last two sources of carbon, namely fructose and maltose manifest the ability of Saccharomyces cerevisiae to concentrate conditions of culture.

d)-Chemical analysis of the sample after treatment with different carbon source for uranium and thorium is presented in Table (3). From the results it 
is obvious that $\mathrm{U}$ and Th content is lowered with all carbon source except in lactose, for more precise inspection of the results, one can notice that starch and maltose experiments gave the same order of results for $U$ and Th namely $13 \mathrm{ppm}$ for $\mathrm{U}$ and 6, $4 \mathrm{ppm}$ for Th while the control sample (bulk) gave 35 and $17 \mathrm{ppm}$ for $\mathrm{U}$ and $\mathrm{Th}$, respectively. The same situation was noticed for glucose and sucrose results, 22 and $20 \mathrm{ppm}$ for $\mathrm{U}$ and 8 and $7 \mathrm{ppm}$ for Th, respectively. Fructose lowers the uranium concentration from $35 \mathrm{ppm}$ to 14 ppm and concentration from 17 to 9 for Th.

e)-Radiometric analysis of the control untreated sample and the treated samples after utilizing different carbon sources for uranium, thorium and radium is prevailed in Table (4):

The same decreasing $\mathrm{U}$ and Th concentration trend with observed overall the different carbon sources. The particular differences between the experimental results that starch, lactose, fructose and glucose experiments gave nearly the same $\mathrm{U}$ retention results $22,22,23$, and $24 \mathrm{ppm}$ respectively compared with the original untreated sample with $45 \mathrm{ppm}$ for uranium concentration, while sucrose and maltose experiments gave 17 and $18 \mathrm{ppm}$ Uranium. In the same time fructose and sucrose experiments result in the lowest thorium concentration $2 \mathrm{ppm}$ compared with the control untreated sample of $13 \mathrm{ppm}$ thorium concentration. While starch and glucose experiments results were 6 $\mathrm{ppm}$ for thorium. Maltose and lactose experiment give $4 \mathrm{ppm}$ and $9 \mathrm{ppm}$ for the persisted thorium. Radium geometric analysis for the original untreated sample gave $15 \mathrm{ppm}$ while cultured phosphogypsum samples using glucose and lactose as carbon sources gave $18 \mathrm{ppm}$ for each, which increase the concentration of the element. Experiments of sucrose result in $\mathrm{Ra}$ concentration about $29 \mathrm{ppm}$ a double elemental value. Starch, maltose and fructose experiments give a bit lowered radium value i.e. 11, 12 and $13 \mathrm{ppm}$ respectively.

\section{Discussion}

Paul et al; (2007) reported that, the main sources of energy for many types of yeast are sugars which are oxidized in respiratory processes within the yeast cell.

Oxygen is not required for the first step of oxidation nevertheless; the sugar is broken down to a simple organic acids and energy released in the respiratory process. If Oxygen supply is ample this acid is oxidized. With the release of relatively large amount of energy and the yeast will multiply rapidly. Results 
obtained showed differences in elements through applying different carbon sources and are agreement with Samuel et al; (2016).

\section{The results obtained from the present study showed that:}

- $\mathrm{Na}_{2} \mathrm{O}$ showing increases in the six types of sugar (starch, maltose, glucose, sucrose, lactose and fructose) and reach its higher value in sucrose media.

- $\mathrm{MgO}$ recorded higher value in sucrose media with higher value in other five types.

- $\mathrm{Al}_{2} \mathrm{O}_{3}$ recorded in glucose medium was higher than these of lactose, Maltose, starch and sucrose.

- $\mathrm{SiO}_{2}$ showing high values in maltose than the other.

- $\mathrm{P}_{2} \mathrm{O}_{5}$ showing decreasing in all types of sugar (starch, maltose, glucose, sucrose, lactose and fructose) and reach its maximum decreasing in starch.

- $\mathrm{SO}_{3}$ showing decreasing in all types of sugar and reach its maximum decreasing in maltose media.

- Uranium recorded decreasing in all additionally it reaches to maximum declining in starch and maltose media.

- Thorium recorded decreasing in five types only (starch, maltose, glucose, sucrose, and fructose) and its maximum decreasing was in maltose.

$-\mathrm{K}_{2} \mathrm{O}$ nearly the same results in all types of sugar

$-\mathrm{CaO}$ showing decreasing in all types of sugar and reach its maximum decreasing in sucrose media.

- $\mathrm{TiO}_{2}$ disapperaed in all types of sugars except increase in lactose media.

- $\mathrm{Fe}_{2} \mathrm{O}_{3}$ showing higher value in all and reach the maximum in sucrose media.

- Radium shows increasing in lactose, glucose and sucrose, while decrease in starch, maltose and fructose media.

These results are in agreement with (Samuel et al; 2016) who reported that, toxic metals eliminated, recovered precious metals and clean radionuclides by S. cerevisiae.The recovery of light metals, such as aluminum by $S$. cerevisiae. Wanda et al; (2005) proved that, the yeast cells of $S$. cerevisiae treated with hot alkali were capable of accumulating a wide range of heavy metal cations $\left(\mathrm{Fe}^{3+}, \mathrm{Cr}^{3+}, \mathrm{Cu}^{2+}, \mathrm{Hg}^{2+}, \mathrm{Pb}^{2+}, \mathrm{Ni}^{2+}, \mathrm{Cd}^{2+}, \mathrm{Co}^{2+}, \mathrm{Ag}^{+}\right.$, and $\left.\mathrm{Fe}^{2+}\right)$. Lead. Cadmium, copper, zinc, chromium, nickel, silver and uranium, etc. have been studied much more than cobalt, molybdenum, iron, manganese, radium selenium, lanthanide, precious metals. 
Table (1): Scan - microscope analysis for the control sample and cultured samples after applying different carbon sources

\begin{tabular}{|c|c|c|c|c|c|c|c||}
\hline $\begin{array}{c}\text { Elements } \\
\%\end{array}$ & $\begin{array}{c}\text { Control } \\
\text { sample }\end{array}$ & \multicolumn{7}{|c|}{ Carbon Sources } \\
\cline { 3 - 8 } & Glucose & Sucrose & Fructose & Lactose & Maltose & Starch \\
\hline $\mathrm{Na}_{2} \mathrm{O}$ & 1.96 & 2.60 & 4.04 & 3.67 & 3.91 & 3.42 & 3.32 \\
\hline $\mathrm{MgO}$ & N.D & 0.69 & 0.71 & 0.42 & 0.55 & 0.36 & 0.35 \\
\hline $\mathrm{Al}_{2} \mathrm{O}_{3}$ & 1.5 & 2.31 & 1.75 & 2.02 & 1.71 & 1.57 & 1.56 \\
\hline $\mathrm{SiO}_{2}$ & 5.12 & 5.62 & 7.74 & 7.06 & 8.91 & 12.5 & 8.18 \\
\hline $\mathrm{P}_{2} \mathrm{O}_{5}$ & 3.23 & 2.72 & 2.64 & 2.55 & 2.63 & 2.56 & 2.41 \\
\hline $\mathrm{SO}_{3}$ & 45.98 & 44.49 & 42.17 & 45.85 & 43.11 & 42.07 & 45.13 \\
\hline $\mathrm{ThO}_{2}$ & 0.18 & N.D & N.D & N.D & N.D & N.D & N.D \\
\hline $\mathrm{UO}_{2}$ & 0.33 & N.D & N.D & N.D & N.D & N.D & N.D \\
\hline $\mathrm{K}_{2} \mathrm{O}$ & 1.52 & 1.43 & 1.88 & 1.73 & 1.52 & 1.87 & 1.81 \\
\hline $\mathrm{CaO}^{n}$ & 36.51 & 36.34 & 31.75 & 33.31 & 32.76 & 32.17 & 33.59 \\
\hline $\mathrm{TiO}_{2}$ & 0.41 & N.D & N.D & N.D & 0.57 & N.D & N.D \\
\hline $\mathrm{Fe}_{2} \mathrm{O}_{3}$ & 3.26 & 3.80 & 7.32 & 3.39 & 4.33 & 3.48 & 3.65 \\
\hline $\mathrm{Total}^{n}$ & 100.00 & 100.00 & 100.00 & 100.00 & 100.00 & 100.00 & 100.00 \\
\hline
\end{tabular}

N.D $=$ Not detected 


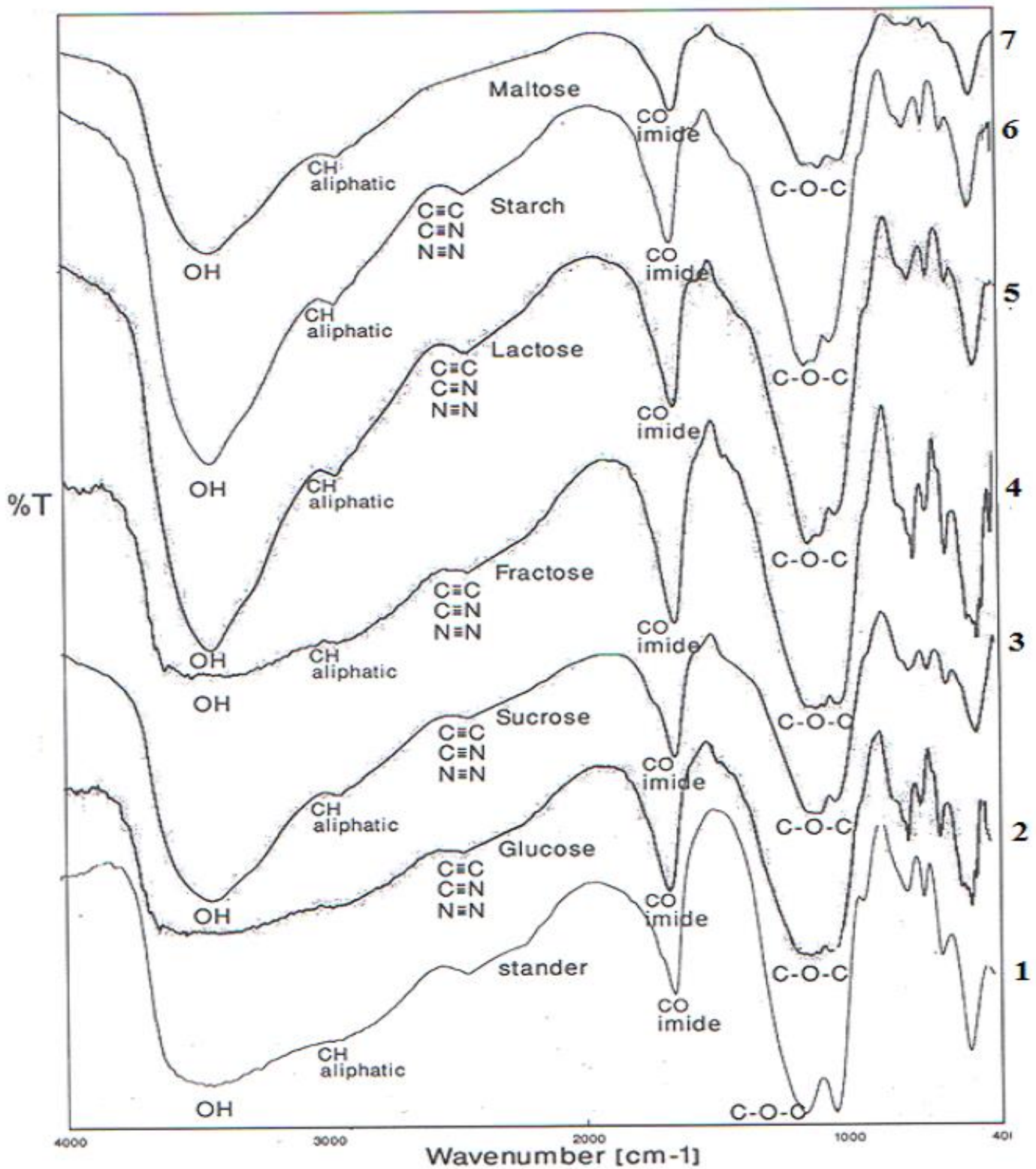

Figure (1): Infra Red analysis for the control sample and cultured samples after applying different carbon sources: 1-Control sample 2- Glucose 3- Sucrose 4Fructose 5- Lactose 6- Starch 7- Maltose. 
Table (2): X-Ray fluorescence (XRF) Analysis for the control sample and cultured samples after applying different carbon sources

\begin{tabular}{|c|c|c|c|}
\hline & Major & Minor & Trace Element \\
\hline Control & $\mathrm{S}$ & $\mathrm{Ca}$ & $\begin{array}{c}\mathrm{Mn}, \mathrm{Cr}, \mathrm{Cu}, \mathrm{Zn}, \mathrm{Sr}, \mathrm{Y}, \mathrm{Zr}, \mathrm{Pd}, \mathrm{Ag}, \mathrm{Si} \\
\mathrm{Fe}, \mathrm{K} \text { and } \mathrm{Ti}\end{array}$ \\
\hline Lactose & $\mathrm{S}$ & $\mathrm{Ca}$ & $\begin{array}{c}\mathrm{Mn}, \mathrm{Cr}, \mathrm{Cu}, \mathrm{Zn}, \mathrm{Sr}, \mathrm{Y}, \mathrm{Zr}, \mathrm{Rb}, \mathrm{Si}, \mathrm{Fe}, \mathrm{K} \\
\text { and } \mathrm{Ti} .\end{array}$ \\
\hline Glucose & $\mathrm{S}$ & $\mathrm{Ca}$ & $\begin{array}{c}\mathrm{Mn}, \mathrm{Cr}, \mathrm{Cu}, \mathrm{Zn}, \mathrm{Sr}, \mathrm{Y}, \mathrm{Zr}, \mathrm{Ni}, \mathrm{Si}, \mathrm{Fe}, \mathrm{K} \\
\text { and } \mathrm{Ti} .\end{array}$ \\
\hline Sucrose & $\mathrm{S}$ & $\mathrm{Ca}$ & $\begin{array}{c}\mathrm{Mn}, \mathrm{Cr}, \mathrm{Cu}, \mathrm{Zn}, \mathrm{Sr}, \mathrm{Y}, \mathrm{Zr}, \mathrm{Rb}, \mathrm{Cl}, \mathrm{Si}, \mathrm{Fe}, \\
\mathrm{K} \text { and } \mathrm{Ti}\end{array}$ \\
\hline Starch & $\mathrm{S}$ & $\mathrm{Ca}$ & $\begin{array}{c}\mathrm{Mn}, \mathrm{Cr}, \mathrm{Cu}, \mathrm{Zn}, \mathrm{Sr}, \mathrm{Y}, \mathrm{Zr}, \mathrm{Si}, \mathrm{Fe}, \mathrm{K} \text { and } \\
\mathrm{Ti} .\end{array}$ \\
\hline Fructose & $\mathrm{S}$ & $\mathrm{Ca}$ & $\begin{array}{c}\mathrm{Mn}, \mathrm{Cr}, \mathrm{Cu}, \mathrm{Zn}, \mathrm{Sr}, \mathrm{Y}, \mathrm{Zr}, \mathrm{Nb}, \mathrm{Rb}, \mathrm{Si}, \mathrm{Fe}, \\
\mathrm{K} \text { and } \mathrm{Ti}\end{array}$ \\
\hline Maltose & $\mathrm{S}$ & $\mathrm{Ca}$ & $\begin{array}{c}\mathrm{Mn}, \mathrm{Cr}, \mathrm{Cu}, \mathrm{Zn}, \mathrm{Sr}, \mathrm{Y}, \mathrm{Zr}, \mathrm{Nb}, \mathrm{Rb}, \mathrm{Ni}, \mathrm{Si}, \\
\mathrm{Fe}, \mathrm{K} \text { and } \mathrm{Ti}\end{array}$ \\
\hline
\end{tabular}

Table (3): Chemical analysis of Uranium and Thorium to the control sample and cultured samples after applying different carbon sources:

\begin{tabular}{|c|c|c|}
\hline \multirow{2}{*}{ sample } & \multicolumn{2}{|c|}{ Radioactive Elements } \\
\cline { 2 - 3 } & U (ppm) & Th (ppm) \\
\hline control sample & 35 & 17 \\
\hline Starch & 13 & 6 \\
\hline Maltose & 13 & 4 \\
\hline Glucose & 22 & 8 \\
\hline Sucrose & 20 & 7 \\
\hline lactose & 37 & 20 \\
\hline Fructose & 14 & 9 \\
\hline
\end{tabular}




\section{Table (4): Radiometric analysis of Uranium, Thorium and Radium to control sample and cultured samples after applying different carbon sources:}

\begin{tabular}{|c|c|c|c|}
\hline Sample & $\mathrm{U}(\mathrm{ppm})$ & $\mathrm{Th}(\mathrm{ppm})$ & $\mathrm{Ra}(\mathrm{ppm})$ \\
\hline Control & 45 & 13 & 15 \\
\hline Glucose & 24 & 6 & 18 \\
\hline Lactose & 22 & 9 & 18 \\
\hline Fructose & 23 & 2 & 13 \\
\hline Sucrose & 17 & 2 & 29 \\
\hline Starch & 22 & 6 & 11 \\
\hline Maltose & 18 & 4 & 12 \\
\hline
\end{tabular}

U: Uranium, Th: Thorium, Ra: Radium

\section{Summary and Conclusion}

Saccharomyces cerevisiae was utilized as microorganism to work on Th, U and $\mathrm{Ra}$ which represented the main radioactive components of the phosphogypsum samples. Many analytical techniques were applied to find out and monitor all the changes in the phosphogypsum samples correlated to the change in radioactive elements levels after each experiment e.g. IR, XRF, Chemical analysis for radiometric elements, Geometric analysis and scan electron microscope. From the obtained data it was found that U, Th content in phosphogypsum sample were decreased markedly after treatment with all kinds of carbon sources especially with starch, glucose and fructose. Radium content in the same time was increased slightly in most cases. From these data Saccharomyces cerevisiae may be utilized under certain circumstances for $\mathrm{U}$ and Th biosorption from phosphogypsum samples.

\section{Reference}

Anderson R., Lovley R., (2002): Microbial redox interactions with uranium: an environmental perspective In M. J. Keith-Roach and F. R. Livens, 
Interactions of microorganisms with radionuclides", Elsevier Science Ltd., Amsterdam.44: 205-223.

Aytas S., Turkozu A., Gok C., (2011). Biosorption of uraniurn(VI) by bifunctionalized low biocomposite adsorbent. Desalination, 280: 354-362.

Carbonell A., DeLaune D., Jugsujinda A., (2002). Phosphogypsum chemistry under highly anoxic conditions. Waste Management. 22: 657-665.

Dorota W., Andrzej B., (2009). Phosphogypsum biotransformation in cultures of sulphate reducing bacteria in whey (International Biodeterioration and Biodegradation). 63:322-327.

Erdmanna N., Bettia M., Stetzera O., Tamborinia G., Kratzb J., Trautmann N., (2000). Production of monodisperse uranium oxide particles and their characterization by scanning electron microscopy and secondary ion mass spectrometry. Spectrochimica Acta Part B: Atomic Spectroscopy J., (55): 1565-1575.

Gravani K., Papachristodoulou C., Oikonomou A., Ioannides A. (2006). Analytica Chimica Acta, 347: 573-574.

Guidelines for Management, Handling, (2014). Utilization and Disposal of Phosphogypsum Generated from Phosphoric Acid Plants" Central pollution control board (Ministry of Environment, Forests \& Climate Change) Parivesh Bhawan, East Arjun Nagar.

Liu M., Zhang D., Kang H., (2010). The effect of strontium stress to yeast cell antioxidant enzyme activities under acute conditions, Conference on Environmental Pollution and Public Health. Wuhan: Scientific Research Press, USA: 367-370.

Liu M., Dong F., Yan X., Zeng W., Hou L., Pang X., (2010). Biosorption of uranium by Saccharomyces cerevisiae and surface interactions under culture conditions, Bioresource Technology 101: 8573-8580.

Lloyd J., (2003). Microbial reduction of metal and radionuclides. FEMS Microbiol. Rev. 27:411-425.

Lovley D., Widman K., Woodward C., Philips P., (1993). Reduction of uranium by cytochrome $c_{3}$ of Desulfovibrio vulgaris. Appl. Environ. Microbiol. 59:3572-3576.

Marczenko Z., (1986). Separation and Spectrophotometric Determination of Elements. John Wiely \& sons, Toronto.

Matolin M., (1991). Construction and use of spectrometric calibration pads, Laboratory of Gamma-ray spectrometry, N.M.A., Egypt A report to the Government of the Arab Republic of Egypt. Project Egy., 4, 030-03, 
Nealson K., Belz A., McKee B., (2002). Breathing metals as a way of life: geobiology in action". Antonie Leeuwenhoek .81:215-222.

Norrish K., Chappell B., (1967). X-ray fluorescence spectrography. In J. Zussman (ed.) Physical Methods in Determinative Mineralogy, Academic Press, New York, 161-214.

Ohnuki T., Yoshida T., Ozaki T., (2005) Interactions of uranium with bacteria and kaolinite clay. Chemical Geology 220: 237-243.

Oliveira S., Imbernon R., (1998). Weathering alteration and related REE concentration in the Catalão I carbonatite complex, central Brazil. J. of South American Earth Sciences. 11: 379-388.

Parreira A., Kobayashi K., Silvestre B., (2003). Influence of Portland cement type on unconfined compressive strength and linear expansion of cement stabilized Phosphogypsum. J. of Environ. Eng., 129: 956-960.

Paul J., Nicholas P., Brandt L., Ivan R., Mike T., Bruce F., (2007). The Size of the Nucleus Increases as Yeast Cells Grow, Mol Biol Cell. 18: 35233532.

Peter L., (2011). Infrared and Raman Spectroscopy. Principles and Spectral Interpretation., 1-5.

Sakamoto M., Siqueira F., Rôças I., Benno Y., (2007). Bacterial reduction and persistence after endodontic treatment procedures. Oral Microbiol Immunol 22: 19-23.

Samia A., Mechichi T.,Sami S., (2005). Sulfate reduction from Phosphogypsum using a mixed culture of sulfate-reducing bacteria. J. of Intern. Biodeter. and Biodegrad., 56: 236-242.

Samuel M., Rafael D., Ivan P., Fabio P., (2016). Magnesium capability to attenuate the toxicity of aluminum on the growth of Saccharomyces cerevisiae PE-2, Braz. J. Food Technol. vol.19 Campinas.

Sani R., Peyton A., Smith A., Peterson N. (2002). Dissimilatory reduction of $\mathrm{Cr}(\mathrm{VI}), \mathrm{Fe}(\mathrm{III})$, and $\mathrm{U}(\mathrm{VI})$ by Cellulomonas isolates". Appl. Microbiol. Biotechnol. 60:192-199.

Sarri S., Misaelides P., Papanikolaou M., Zamboulis D., (2009) Uranium removal from acidic aqueous solutions by saccharomyces cerevisiae, Debaryomyces hansenii, Kluyveromyces marxianus and Candida colliculosa, J. Radioanal. Nucl. Chem., 279: 709-711.

Shelobolina E., Sullivan A., O'Neill R., Nevin P., Lovley R., (2004). Isolation, characterization, and U(VI)-reducing potential of a facultatively anaerobic, acid-resistant bacterium from low-pH, nitrate and U(VI)- 
contaminated subsurface sediment and description of Salmonella subterranea sp. nov". Appl. Environ. Microbiol. 70: 2959-2965.

Viswanathan G., (1989). Marks of Conquest Literary Study and British Rule in India. London: Faber and Faber.

Wanda D., Magorzata G., Stanisaw B., Adam B., (2005). Studies into Saccharomyces Cerevisiae baker's yeast capacity for binding Magnesium under batch conditions, Polish journal of food and nutrition sciences, 14/55: 249-255.

Wolicko D., Kowalski w., Boszczyk M., (2005). Biotransformation of Phosphogypsum by bacteria isolated from petroleum- refining waste waters, J. of Microbiology. 54: 169-173.

Xinjin L., Laszlo C. and Gadd M., (2016). Uranium bioprecipitation mediated by yeasts utilizing organic phosphorus substrates, Appl Microbiol Biotechnol 100: 5141-5151.

Yang J., Liu W., Zhang L., Xiao B., (2009). Preparation of load-bearing building materials from autoclaved phosphogypsum. Construction and Building Materials 23, 687-693. 
الامتصاص الحيوي للعناصر المشعه من الجبس الفسفوري بواسطه الخميره

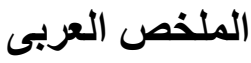

الجبس الفسفوري هو منتج ثانوي صناعي مهم مستمد من تصنيع حامض الفوسفوريك وسماد الفوسفات بو اسطة عملية نزع الماء. بواسطه استخدام فطر الخميرة كمتص بيولوجي لليورانيوم ،الثوريوم والر اديوم من الجبس الفسفوري في وجود مصسادر كربونيه مختلفة مثل المالتوز و السكروز و النشا واللاكتوز و الفركتوز والجلوكوز.وقد وجد ان بيئة النشا، المالتوزو الفركتوز تعطي اعلى قدرة علي الامتصاص الحيوى لليور انيوم (13، 13 و 14 جزء في المليون) بينما مع السكروز و الجلوكوز تعطي (20 و 22 جزء في المليون) علي التوالي. بينما بيئة المالتوز والنشا تعطي أعلى قدرة امتصاص حيوي للتوريوم وفي نفس الوقت السكروز والجلوكوز تعطي قدرة امتصاص حيوى متوسط في حين اللاكتوز يعطي أدنى نتيجة. 